Published by LPMP Imperium

Journal homepage: https:/ / ejournal.imperiuminstitute.org/index.php/ AKURASI

\title{
Peran Fintech Dalam Upaya Untuk Meningkatkan Literasi Keuangan Pada Masyarakat di Jakarta
}

\section{Siti Ruhana Dara*, Mariah}

Fakultas Bisnis, Institut Teknologi dan Bisnis Kalbis, Jakarta, Indonesia

\begin{abstract}
This study aims to analyze the effect of fintech as measure by the TAM measurment model, with perceive usefulness and perceive ease of use with financial literacy for dependent variable. The research consist of 110 respondents who filled out a questioneras research data. The analysis used is multiple linear regression. The result show that perceive usefulness and perceive ease of use affect financial literacy.while partial, perceive usefulness affect financial literacy but perceive ease of use has no effect to financial literacy.
\end{abstract}

Keywords:

Fintech, Perceive Usefulness, Perceive ease of use, financial literacy

\section{Corresponding Author:}

Siti Ruhana Dara1, Manajemen, Fakultas Bisnis

Institute Teknologi dan Bisnis Kalbis.

Jl. Pulomas Selatan Kav.22 Jakarta, Indonesia

Email: siti.dara@kalbis.ac.id

(C) The Author(s) 2020

DOI: https:/ / doi.org/ 10.36407/ akurasi.v2i3.240

\section{(c) (4)}

CC BY: This license allows reusers to distribute, remix, adapt, and build upon the material in any medium or format, so long as attribution is given to the creator. The license allows for commercial use.

\section{Research Paper}

Financial Management

Received: 27 Sep 2020

Revised: 20 Oct 2020

Accepted: 02 Dec 2020

Online: 20 Dec 2020

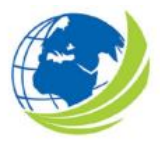

Akurasi: Jurnal Riset Akuntansi dan Keuangan, Vol 2, No.3, 2020, pp. 127 - 138

eISSN 2685-2888 


\section{PENDAHULUAN}

Fintech atau financial technology menurut Bank Indonesia merupakan gabungan antara jasa keuangan dengan teknologi yang akhirnya mengubah model bisnis dari konvensional menjadi moderat, yang awalnya dalam membayar harus bertatap muka dan membawa sejumlah uang kas, kini dapat melakukan transaksi jarak jauh dengan melakukan pembayaran yang dapat dilakukan dalam hitungan detik saja. Dalam sektor keuangan mungkin teknologi ataupun perkembangan teknologi bukan hal yang baru, karena perkembangannya selalu diikuti oleh sektor tersebut. Fintech hadir untuk memudahkan masyarakat agar lebih mudah dan efektif dalam menggunakan segala layanan keuangan. Beberapa contoh bisnis yang tergabung di dalam fintech antara lain proses jual beli saham, pembayaran, peminjaman uang (lending) peer to peer, perencanaan keuangan, investasi ritel dan lain sebagainya.

Mengacu pada hasil Survei APJI (Asosiasi Penyelenggara Jasa Internet Indonesia) tahun 2018, Pulau Jawa memiliki presentase 55,7\% untuk pengguna internet perwilayah, paling tinggi dibandingkan dengan pulau Sumatera, Sulawesi-maluku-papua, Kalimantan, Bali \& Nusa Tenggara. Undang-undang Nomor 21 Tahun 2011 tentang Otoritas Jasa Keuangan (OJK) mengamanatkan Otoritas Jasa Keuangan untuk mengatur dan mengawasi industri keuangan sekaligus melindungi kepentingan masyarakat dalam berinteraksi dengan industri jasa keuangan. Dalam melindungi kepentingan terdapat aspek literasi dan inklusi keuangan yang memerlukan strategi tersendiri dalam implementasinya.

Menurut data OJK sampai dengan Tanggal 11 Juni 2020, terdapat 160 Fintech lending berizin dan terdaftar di OJK. Klasifikasi fintech antara lain crowdfunding dan peer to peer lending, market aggregator, risk and investment management dan payment, settlement and clearing. Kita dapat menganalisa faktor yang mempengaruhi diterima atau tidaknya suatu system informasi dengan menggunakan Technology acceptance model yang diperkenalkan pertama kali oleh Fred Davis pada tahun 1989 dan beberapa revisi telah diperkenalkan sampai terakhir dikembangkan oleh Venkhates \& Davis pada tahun 1996. Dimana, ada tiga faktor yang mempengaruhi sebuah system antara lain perceived usefulness, perceive ease of use (Surendran, 2012). Aliyah dan Nurdin (2019) menggunakan dua variable ini untuk mewakili pengukuran fintech untuk masyarakat Dago atas, Bandung, mendapatkan hasil bahwa terdapat pengaruh positif antara persepsi kemudahan terhadap literasi, dan pengaruh positif antara persepsi kemanfaatan terhadap literasi keuangan.

Inklusi keuangan tidak hanya sebatas pengembangan produk dan layanan jasa keuangan, tetapi juga meliputi empat elemen inklusi keuangan lainnya yaitu; perluasan akses keuangan, ketersediaan produk dan layanan jasa keuangan, penggunaan produk layanan jasa keuangan, serta peningkatan kualitas baik kualitas penggunaan produk dan layanan jasa keuangan itu sendiri. Inklusi keuangan itu sendiri didefinisikan sebagai hak setiap orang untuk memiliki akses dan layanan penuh dari lembaga keuangan secara tepat waktu, nyama, informatif dan terjangkau biayanya, dengan penghormatan penuh kepada harkat dan martabatnya.

Dapat terlihat gambar 1.1 adalah financial inclusion index yang di dapat dari International Monetary Fund (2020, P.25) yang menjelaskan inklusi keuangan menggabungkan tradisional dan digital, tradisional berbasis bank sedangkan digital berbasis fintech, dimana masing-masing menggabungkan antara indikator akses dan penggunaan 
layanan.untuk tradisional akses melalui bank dan penggunaan layanan dengan ATM, sedangkan untuk digital aksess internet dan pengguna oleh financial institusion.

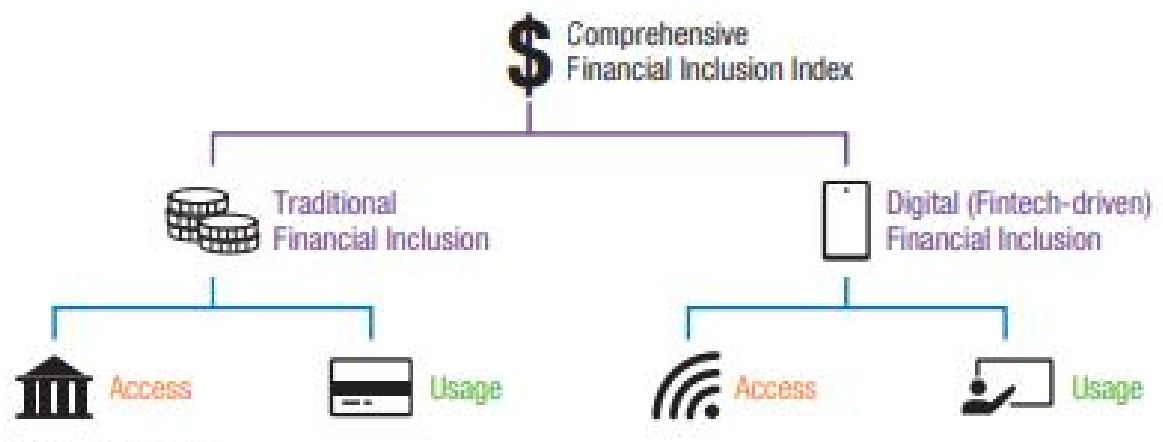

Source: IMF staff.

\section{Gambar 1.}

Financial Inclusion Index

Sumber : IMF, 2020

Menurut data World Bank Tahun 2017, Indonesia tertinggal dalam hal Literasi keuangan dengan hanya mencakup 32\% dari total penduduk, sedangkan malaysia dan singapura masing-masing mencapai 36\% dan 59\% disusul dengan Thailand 27\%, Filipina 25\%, Vietnam $24 \%$ dan cambodia 18\%. Dibawah ini adalah data tingkat literasi keuangan dan inklusi keuangan nasional.

- Literasi Keuangan Inklusi Keuangan

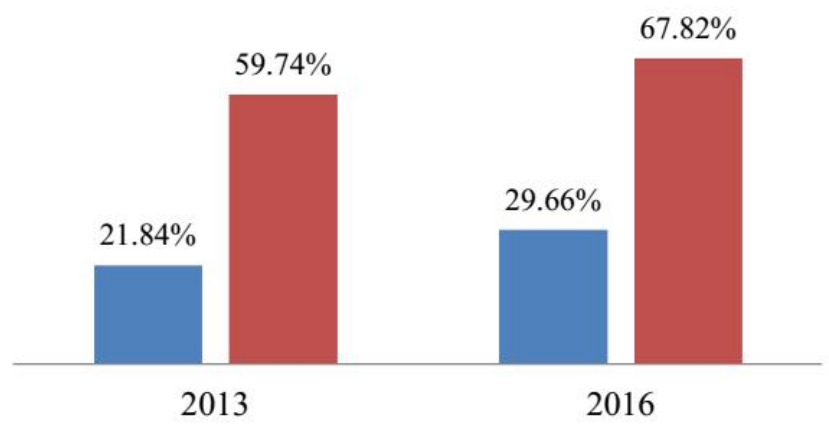

\section{Gambar 2.}

Tingkat Literasi dan Inklusi Keuangan

Sumber: OJK(2016)

Dalam data pada gambar 2 dapat dilihat adanya ketimpangan antara inklusi keuangan dengan literasi keuangan. Literasi keuangan dapat dijelaskan sebagai pengetahuan tentang produk-produk keuangan maupun lembaga keuangan. Jadi, dari data sapat disimpulkan bahwa masyarakat mampu mengakses keuangan dan jasa keuangan namun belum memiliki pemahaman serta pengetahuan yang baik terhadap layanan tersebut. 
Data dari OJK tahun 2016 untuk tingkat literasi keuangan per wilayah, dapat dilihat pada gambar 1.3 bahwa DKI Jakarta memiliki nilai paling tinggi dibandingkan wilayah lainnya di Indonesia yaitu 40\% tingkat literasi keuangannya, dan yang paling kecil adalah Papua Barat dengan tingkat literasinya 19,27\%. Tertinggi kedua adalah wilayah Jawa Barat dengan persentase 38,70\% dan kedua terendah adalah Papua 22,18\%. Dari gambar tersebut dapat menjelaskan bahwa literasi masyarakat DKI Jakarta paling tinggi dibandingkan dengan wilayah lainnya, hal ini bisa didukung karena Jakarta adalah ibukota dari negara Indonesia, yang merupakan pusat pemerintahan dan segala informasi dekat dan mudah untuk di sebarkan. Tetapi tingkat persentase yang besar belum tentu dapat kita generalisir dengan pemahaman yang baik untuk literasi keuangannya. Studi ini bertujuan untuk menguji peran fintech dalam upaya untuk meningkatkan literasi keuangan pada masyarakat di Jakarta dimana penggunaan Fintech dapat kita ukur dari Persepsi kemanfaatan dan persepsi kemudahan sesuai dengan teori TAM.

\section{KAJIAN PUSTAKA}

\section{Financial Technology}

Menurut Financial Stability Board (2017) Financial technology atau teknologi keuangan atau yang biasa disebut dengan fintech, didefinisikan sebagai inovasi teknologi dalam layanan keuangan yang dapat menghasilkan model-model bisnis, aplikasi, proses atau produk produk dengan efek material yang terkait dengan penyediaan layanan keuangan. Fintech juga turut membantu masyarakat untuk lebih mudah mendapatkan akses terhadap produk keuangan dan literasi keuangan (Finansialku, 2018). Klasifikasi fintech menurut Bank Indonesia ada beberapa macam yaitu:

1. Crowdfunding dan peer to peer lending, adalah teknik pendanaan unit usaha atau proyek usaha yang melibatkan manusia secara luas (Akbar, D.S, 2015). Peer to peer lending ( $\mathrm{P} 2 \mathrm{P}$ Lending) adalah praktik atau metode memberikan pinjaman uang kepada individu atau bisnis dan juga sebaliknya, mengajukan pinjaman pada pemberi pinjaman yang menghubungkan antara pemberi pinjaman dengan peminjam atau investor secara online (Walter, 2019).

2. Market Aggregator. Menurut CNBC Indonesia (2018) Market aggregator yaitu mengumpulkan dan mengelola data yang bisa dimanfaatkan konsumen untuk membantu pengambilan keputusan.

3. Risk and Invesment Management, atau biasa yang disebut dengan risiko dan investasi manajemen dalam financial technology digunakan sebagai perencanaan dalam bentuk digital.

4. Payment, Settlement and Clearing. Dalam CNBC Indonesia (2018) Payment, settlement dan clearing adalah sektor fintech yang dengan layanan sistem pembayaran baik yang diselenggarakan oleh industri perbankan atau lembaga Bank Indonesia

Menurut International Trade Administration (2016), Financial Techology merupakan sebuah "revolusi" atas penggabungan jasa keuangan dengan teknologi informasi yang telah meningkatkan kualitas layanan keuangan, dan menciptakan stabilitas keuangan. The National Digital Research Centre di Dublin (2014) Mendefinisikan Financial Technology adalah sebuah inovasi dalam jasa keuangan dengan memanfaatkan perkembangan teknologi informasi. FinTech menunjuk pada pengunaan teknologi untuk memberikan solusi-solusi keuangan (Arner, et al., 2015).

\section{Technology Acceptance Model (TAM)}

Technology Acceptance Model (TAM ) adalah salah satu model yang dapat digunakan untuk menganalisis faktor- faktor yang mempengaruhi diterimanya suatu sistem / sistem 
informasi. Teori ini pertama kali dikembangkan oleh Davis (1989) yang merupakan salah satu model yang popular untuk memprediksi kegunaan dan penerimaan sistem informasi dan teknologi by individual users. Dalam TAM terdapat dua faktor yang relevan dalam prilaku penggunaan terhadap teknologi, yaitu:

1. Persepsi Kemanfaatan (Perceived Usefulness). Davis, et al., (1989) mendefinisikan Perceived Usefulness sebagai keyakinan akan kemanfaatan, yaitu tingkatan dimana user percaya bahwa penggunaan teknologi atau sistem akan meningkatkan kinerjanya dalam bekerja.

2. Persepsi Kemudahan Penggunaan (Perceived Ease of Use). Davis et al. (1989) mendefinisikan percieved ease of use sebagai keyakinan akan kemudahan penggunaan, yaitu tingkatan dimana user percaya bahwa teknologi atau sistem tersebut dapat digunakan dengan mudah dan bebas dari masalah.

\section{Literasi Keuangan}

Peningkatan Literasi dan Inklusi Keuangan di sektor Jasa Keuangan Bagi Konsumen dan atau Masyarakat, literasi keuangan adalah pengetahuan, keterampilan, keyakinan, yang memengaruhi sikap dan perilaku untuk meningkatkan kualitas pengambilan keputusan dan pengelolaan keuangan dalam rangka mencapai kesejahteraan. Organization for Economic Cooperation and Development (2016) mendefinisikan literasi keuangan sebagai pengetahuan dan pemahaman atas konsep dan risiko keuangan, berikut keterampilan, motivasi, serta keyakinan untuk menerapkan pengetahuan dan pemahaman yang dimilikinya tersebut dalam rangka membuat keputusan keuangan yang efektif, meningkatkan kesejahteraan keuangan (financial well being) individu dan masyarakat, dan berpartisipasi dalam bidang ekonomi. Menurut OECD/ INFE (2016), definisi literasi keuangan adalah kombinasi kesadaran, pengetahuan, keterampilan, sikap dan perilaku yang diperlukan untuk membuat keputusan finansial untuk mencapai tujuan akhir yaitu mencapai kesejahteraan finansial individu. Menurut Welly et al. (2016) literasi keuangan adalah kemampuan (kecakapan) seseorang dalam membuat keputusan yang efektif berhubungan dengan keuangannya. Literasi keuangan membantu individu terhindar dari masalah keuangan terutama yang terjadi akibat kesalahan pengelolaan keuangan.

Atkinson dan Messy (2012), OECD International Network on Financial Education telah mengembangkan sebuah instrumen survei literasi keuangan yang dapat digunakan dengan latar belakang yang sangat berbeda di berbagai negara. Instrumen ini kemudian diperbaharui oleh OECD (2016) dengan menyesuaikan pertanyaan pada tiap instrumen kepada keadaan masyarakat. Tiga komponen instrumen yang digunakan untuk mengukur tingkat literasi keuangan responden ialah:

1. Pengetahuan finansial (financial knowledge), diukur dengan menghitung jumlah tanggapan atau jawaban yang benar oleh masing-masing responden terhadap enam atau lebih pertanyaan terkait pengetahuan perhitungan nilai waktu uang, bunga pinjaman, prinsip perhitungan bunga bank, bunga majemuk, risiko dan laba, definisi dari inflasi, dan diversifikasi.

2. Perilaku finansial (financial behaviour), perhitungan dilakukan berdasarkan jawaban responden dari skor total tujuh pertanyaan yang digunakan untuk mengetahui perilaku finansial responden. Pertanyaan yang diberikan terkait kehati-hatian sebelum melakukan pembelian, ketepatan waktu dalam membayar tagihan, pengaturan tujuan jangka panjang keuangan, aktivitas menabung, keputusan dalam memilih produk finansial, dan pinjaman untuk memenuhi kebutuhan.

3. Sikap finansial (financial attitude), diukur dengan menghitung skor total jawaban responden dari tiga pertanyaan yang diberikan. Pertanyaan terkait dengan bagaimana responden dalam sikap memprioritaskan keinginan jangka pendek daripada keamanan jangka panjang atau membuat rencana keuangan jangka panjang. Tingkat literasi keuangan akan diukur dengan indeks yang dibangun dari jawaban terhadap serangkaian pertanyaan terkait komponen literasi keuangan. 
Dijelaskan dalam Bank Indonesia (2014) Dalam Strategi Nasional Keuangan Inklusif, keuangan inklusif didefinisikan sebagai:

Hak setiap orang untuk memiliki akses dan layanan penuh dari lembaga keuangan secara tepat waktu, nyaman, informatif, dan terjangkau biayanya, dengan penghormatan penuh kepada harkat dan martabatnya. Layanan keuangan tersedia bagi seluruh segmen masyarakat, dengan perhatian khusus kepada orang miskin, orang miskin produktif, pekerja migrant, dan penduduk di daerah terpencil.

Bank Indonesia (2014) mendefinisikan keuangan inklusif (financial inclusion) sebagai seluruh upaya yang bertujuan meniadakan segala bentuk hambatan yang bersifat harga maupun non harga, terhadap akses masyarakat dalam memanfaatkan layanan jasa keuangan. Indikator yang dapat dijadikan ukuran dari keuangan yang inklusif sebuah negara adalah ketersediaan atau akses untuk mengukur kemampuan penggunaan jasa keuangan formal dalam hal keterjangkauan fisik dan harga, penggunaan untuk mengukur kemampuan penggunaan aktual produk dan jasa keuangan (antara lain keteraturan, frekuensi, dan lama penggunaan), kualitas untuk mengukur apakah atribut produk dan jasa keuangan telah memenuhi kebutan pelanggan, dan kesejahteraan untuk mengukur dampak layanan keuangan terhadap tingkat kehidupan pengguna jasa. Otoritas Jasa Keuangan (2016) mendefinisikan inklusi keuangan adalah ketersediaan akses pada berbagai lembaga, produk dan layanan jasa keuangan sesuai dengan kebutuhan dan kemampuan masyarakat dalam rangka meningkatkan kesejahteraan masyarakat. Berdasarkan peraturan Otoritas Jasa Keuangan Nomor 76/POJK.07/2016 tentang peningkatan literasi dan inklusi keuangan di sektor jasa keuangan bagi konsumen dan/ atau masyarakat, tujuan inklusi keuangan meliputi :

1. Meningkatnya akses masyarakat terhadap lembaga, produk dan layanan jasa keuangan pelaku usaha jasa keuangan;

2. Meningkatnya penyediaan produk dan/atau layanan jasa keuangan oleh pelaku usaha jasa keuangan yang sesuai dengan kebutuhan dan kemampuan masyarakat;

3. Meningkatnya penggunaan produk dan/atau layanan jasa keuangan yang sesuai dengan kebutuhan dan kemampuan masyarakat; dan

4. Meningkatnya kualitas penggunaan produk dan layanan jasa keuangan sesuai kebutuhan dan kemampuan masyarakat.

\section{METODE PENELITIAN}

\section{Desain Penelitian}

Jenis Penelitian ini adalah penelitian kuantitatif dengan rumusan masalah asosiatif yang memiliki hubungan kausal, yaitu hubungan yang bersifat sebab akibat. Jadi disini ada variabel independent (variabel yang mempengaruhi) dan dipenden (dipengaruhi) Sugiyono (2012, p. 37). Dimana dalam penelitian ini akan mengetahu pengaruh fintech yang dalam pengukurannya mengacu pada model TAM yaitu mengukur persepsi kemudahan dan persepsi kemanfaatan untuk mengetahui pengaruhnya ke literasi keuangan masyarakat di Jakarta. Untuk data diperoleh dengan menyebarkan kuesioner kepada masyarakat di Jakarta.

\section{Populasi dan Sampel}

Populasi adalah wilayah generalisasi yang terdiri atas: objek/subjek yang mempunyai kualitas dan karakteristik tertentu yang ditetapkan oleh peneliti untuk dipelajari dan kemudian ditarik kesimpulan (Sugiyono, 2012, p. 80). Populasi dalam penelitian ini adalah seluruh masyarakat DKI Jakarta, yang menurut data BPS yang diproyeksikan untuk tahun 2020 adalah sebanyak 10,57 juta jiwa. Menurut data APJI untuk wilayah DKI Jakarta itu sendiri tahun 2018 penetrasi penggunaan internetnya adalah sebesar 80,4\% yang 
dimungkinkan untuk tahun 2020 penetrasi itu semakin bertambah karena ditambah dengan kebijakan sekolah melalui daring membuat semakin banyak yang mengakses internet. Sugiyono (2012,p.81) menjelaskan sampel adalah bagian dari jumlah dan karakteristik yang dimiliki oleh populasi tersebut.

Hair et al. (2006) pengambilan sampel dilakukan dengan menghitung jumlah indikator dikalikan 5, dengan demikian jumlah sampelnya adalah 110 (22 x 5). Untuk Teknik pengambilan sampel dalam penelitian ini dengan menggunakan metode non probability sampling, yaitu teknik pengambilan sampel yang tidak memberikan peluang / kesempatan yang sama bagi setiap unsur atau anggota populasi untuk dipilih menjadi sampel dengan sampling incidental yaitu Teknik penentuan sampel berdasarkan kebetulan, yaitu siapa saja yang secara kebetulan/incidental bertemu dengan peneliti dapat digunakan sebagai sampel (Sugiyono, 2012, p.85), tetapi tetap harus mengacu pada kecocokan sebagai sumber data antara lain masyarakat Indonesia yang tinggal di wilayah DKI Jakarta dan pernah menggunakan salah satu jenis Financial Technology, baik crowdfunding dan peer to peer lending, market aggregator, risk and investment management dan payment, settlement and clearing

\section{Pengukuran Variabel}

Penentuan variable independen dalam penelitian ini menggunakan metode TAM (Technology Acceptance Model) untuk menganalisis faktor-faktor yang mempengaruhi diterimanya fintech atau financial technology. Dua faktor yang mempengaruhi diterimanya fintech adalah persepsi kemanfaatan dan persepsi kemudahan. Jadi terdapat dua variabel independen yaitu persepsi kemanfaatan dan persepsi kemudahan. Variabel dependen atau variabel terikat dalam penelitian ini adalah literasi keuangan (operasionalisasi variabel ditampilkan pada Appendix 1)

\section{Teknik Analisis}

Teknik analisis yang digunakan adalah analisis regresi berganda dengan bantuan alat analisis SPSS untuk mengolah data. Alat analisis yang digunakan untuk mengetahui pengaruh persepsi kemanfaatan dan persepsi kemudahan pengunaan berpengaruh terhadap literasi keuangan masyarakat di Jakarta. Sebelum dilakukan uji asumsi klasik di lakukan uji validitas dan reliabilitas, kemudian uji normalitas, uji multikolinearitas dan heteroskedastisitas .

\section{HASIL DAN PEMBAHASAN}

\section{Deskripsi Responden}

Sebaran responden berdasarkan jenis kelamin, dapat diketahui bahwa Sebagian bedar responden berjenis kelamin perempuan.persentasenya adalah $65 \%$ dan untuk reponden laki laki sebanyak 35\%. Sementara berdasarkan usia, dapat diketahui bahwa sebagian besar responden berumur 31-40 tahun dan 18-30 dengan persentase 49\%:48\%, responden berusia 41-50 tahun adalah sebesar 10\%, sedangkan responden usia $>50$ tahun tidak ada, karena rata-rata dari responden yang saya hubungi, mereka tidak terbiasa mengisi kuesioner dengan menggunakan google form dan juga tidak menggunakan salah satu fintech yang ada.

Sebaran responden berdasarkan Usia, dapat diketahui bahwa sebagian besar responden berumur 31-40 tahun dan 18-30 dengan persentase 49\%:48\%, responden berusia 41-50 tahun adalah sebesar 10\%, sedangkan responden usia>50 tahun tidak ada, karena rata-rata dari responden yang saya hubungi, mereka tidak terbiasa mengisi kuesioner dengan menggunakan google form dan juga tidak menggunakan salah satu fintech yang ada. sebaran responden berdasarkan wilayah tempat tinggal, ditunjukkan bahwa Jakarta Timur memiliki jumlah responden yang banyak, hal ini dikarenakan sebaran kuesioner lebih banyak 
di wilayah sekitar peneliti, persentasenya sebesar 66\%, lalu Jakarta pusat sebesar 13\%, Jakarta utara dan Jakarta Selatan sama sama 11\%, dan Jakarta Barat sebanyak 9\%.

\section{Hasil Uji Hipotesis}

Tabel 1 menunjukan nilai Adjusted R Square adalah sebesar 0,279 (27,9\%) Hal ini menunjukan persentase pengaruh variabel independen financial technology yang diukur dengan persepsi kemanfaatan dan persepsi kemudahan penggunaan mampu menjelaskan variabel literasi keuangan sebesar 27,9\% sedangkan sisanya 72,1\% dijelaskan atau dipengaruhi oleh variabel lain diluar dari variabel penelitian yang ada.

Uji F digunakan untuk mengetahui apakah variabel Persepsi kemanfaatan (X1) dan Persepsi kemudahan penggunaan (X2) secara bersama-sama berpengaruh terhadap variabel Literasi keuangan (Y) atau tidak. Pengujian dilakukan dengan membandingkan F hitung dengan $\mathrm{F}$ tabel. $\mathrm{F}$ tabel dapat dicari dengan menentukan terlebih dahulu derajat kebebasannya yaitu pada $\mathrm{df}=\mathrm{n}-\mathrm{k}=110-2=108$, sehingga didapatkan $\mathrm{F}$ tabel (df, $\mathrm{k}$ ) dengan taraf signifikansi $5 \%=F$ tabel $(108,2)=3,08$. Maka nilai $F$ tabel sebesar 3,08. Jika $F$ hitung $<\mathrm{F}$ tabel maka model tidak signifikan. Dari hasil pengolahan data pada tabel 4.19 diketahu nilai $\mathrm{F}$ hitung 22,077 yaitu lebih besar dari $\mathrm{F}$ tabel 3,08, maka dapat disimpulkan bahwa Persepsi kemanfaatan dan persepsi kemudahan penggunaan secara Bersama sama mempempengaruhi literasi keuangan.

Tabel 1.

Hasil Uji Regresi Linear Berganda

\begin{tabular}{lllll}
\hline & B & Std. Error & t & sig \\
\hline (Constant) & 35.190 & 4,244 & 8,291 &, 000 \\
Persepsi Kemanfaatan (X1) & 1.938 &, 698 &., 776 & .007 \\
Persepsi kemudahan (X2) & .301 &, 630 & .477 & .634 \\
R Square & .292 & & & \\
F-Statistics & 22.077 & & & \\
\hline
\end{tabular}

Sumber : Pengolahan Kuesioner, 2019

Tabel 1 menunjukan hasil uji regresi linier berganda, penjelasan persamaan regresi tersebut sebagai berikut: Konstanta sebesar 35,190, artinya artinya jika variabel persepsi kemanfatan dan persepsi kemudahan penggunaan 0, maka literasi keuangan nilainya 35,190. Koefisien regresi variabel persepsi kemanfaatan sebesar 1,938, artinya jika persepsi kemanfaatan mengalami kenaikan satu satuan, maka literasi keuangan akan mengalami peningkatan sebesar 1,938 satuan dengan asumsi variabel independen lainnya tetap. Koefisien regresi variabel persepsi kemudahan penggunaan sebesar 0,301, artinya jika persepsi kemdahan penggunaan mengalami kenaikan satu satuan, maka literasi keuangan akan mengalami peningkatan sebesar 0,301 satuan dengan asumsi variabel independen lainnya tetap. Pada variabel Persepsi kemanfaatan (X1) memiliki nilai signifikansi sebesar 0,007. Nilai tersebut lebih kecil dari taraf signifikansi 5\%, menyatakan bahwa persepsi kemanfaatan berpengaruh positif terhadap literasi keuangan. Pada variabel Persepsi Kemudahan Penggunaan (X2) memiliki nilai signifikansi sebesar 0,634. Nilai tersebut lebih besar dari taraf signifikansi 5\%, menyatakan bahwa persepsi kemudahan penggunaan tidak berpengaruh terhadap literasi keuangan. 


\section{Tabel 2}

Hasil Mean Variabel persepsi kemanfaatan

\begin{tabular}{lll}
\hline No & Pernyataan & $\begin{array}{l}\text { Nilai } \\
\text { Mean }\end{array}$ \\
\hline 1. & Saya mengetahui Produk Fintech & 4,06 \\
2. & $\begin{array}{l}\text { Saya merasa lebih dimudahkan fintech dalam mengakses produk-produk } \\
\text { keuangan. }\end{array}$ & 4,06 \\
3. & Saya merasa ada manfaat jika bertransaksi dengan menggunakan fintech. & 4,22 \\
\hline
\end{tabular}

\section{Sumber: diolah}

Tabel 2 menunjukan bahwa jawaban dari kuesioner untuk variabel persepsi kemanfaatan yang diberikan kepada 110 responden engan menggunakan skala likert 1-5 dimana angka 1 menunjukan sangat tidak setuju, 2 tidak setuju, 3 cukup setuju, 4 setuju dan 5 sangat setuju. Dalam tabel 4.21 menunjukan nilai mean terendah dari variabel persepsi kemanfaatan (X1) yaitu ada dua 4,06 padaindikator satu dan dua tetapi masih di skala setuju. Dimana responden mengetahu produk fintech dan merasa dimudahkan oleh fintech untuk mengakses produk-produk keuangan. Sedangkan responden merasa ada manfaat menggunakan fintech lebih bedar rata-rata nilainya yaitu 4,22.

Tabel 3.

Hasil Mean Variabel persepsi kemudahan penggunaan

\begin{tabular}{lll}
\hline No & Pernyataan & $\begin{array}{l}\text { Nilai } \\
\text { Mean }\end{array}$ \\
\hline 1. & Saya merasa dimudahkan dalam bertransaksi dengan adanya fintech & 4,27 \\
2. & Saya menggunakan produk fintech karena lebih praktis & 4,26 \\
3. & $\begin{array}{l}\text { Saya berharap akan terus menggunaan produk fintech sebagai alat } \\
\text { pembayaran. }\end{array}$ & 3,90 \\
\hline
\end{tabular}

Sumber: diolah

Tabel 3 menunjukan bahwa jawaban dari kuesioner untuk variabel persepsi kemudahan penggunaan yang telah diberikan kepada 110 responden dengan menggunakan skala likert, dengan skala 1 sampai 5 yang dimana angka 1 menunjukan sangat tidak setuju, 2 tidak setuju, 3 cukup setuju, 4 setuju dan 5 sangat setuju. Dalam tabel 4.17 menunjukan nilai mean terendah dari variabel persepsi kemudahan penggunaan (X2) yaitu 3,90 terdapat pada indikator no 3 yaitu "Saya berharap akan terus menggunaan produk fintech sebagai alat pembayaran" sedangkan untuk indikator 1 dan 2 memiliki nilai yang kurang lebih sama merasa dimudahkan bertransaksi dengan adanya fintech, dan merasa menggunakan fintech karena lebih praktis.

Tabel 4.

Hasil Mean Variabel Literasi Keuangan

\begin{tabular}{llc}
\hline No & Pernyataan & M ean \\
\hline 1 & Saya paham keuangan secara umum. & 3,85 \\
2 & Saya paham bagaimana mengelola keuangan pribadi. & 4,07 \\
3 & Saya mengeluarkan uang sesuai kebutuhan. & 3,98 \\
4 & Saya mengetahui mengenai nilai waktu uang (time value of money) & 3,91 \\
5 & Saya mengetahui risiko dan return & 3,85
\end{tabular}




\begin{tabular}{llr}
6 & Saya mengetahui prinsip penghitungan bunga bank & 3,49 \\
7 & Saya paham perbedaan menabung dan investasi & 4,10 \\
8 & Saya mengetahui mekanisme menabung & 4,16 \\
9 & Saya paham mekanisme Pinjaman & 3,82 \\
10 & Saya mengetahui produk investasi & 3,74 \\
11 & Saya mengenali profil risiko pribadi & 3,59 \\
& Saya mengetahui asuransi untuk perlindungan akibat risiko yang & \\
12 & tidak terduga & 3,67 \\
13 & Saya menyediakan dana darurat & 3,80 \\
15 & Saya selalu berhati-hati dalam mengambil kredit/ hutang & 4,47 \\
16 & Saya selalu membayar tagihan tepat waktu & 4,38 \\
\hline
\end{tabular}

Sumber: diolah

Tabel 4 menunjukan bahwa jawaban dari kuesioner untuk variabel Literasi keuangan yang telah diberikan kepada 110 responden dengan menggunakan skala likert, dengan skala 1 sampai 5 yang dimana angka 1 menunjukan sangat tidak setuju, 2 tidak setuju, 3 cukup setuju, 4 setuju dan 5 sangat setuju. Dalam tabel 4.18 menunjukan nilai mean terendah dari variabel Literasi keuangan (Y) yaitu 3,49 terdapat pada indikator no 6 yaitu "Saya mengetahu prinsi perhitungan bunga bank" ternyata dari responden penelitian, masyarakat masih kurang memahami mengenai perhitungan bunga bank. Nilai lainnya yang juga lebih kecil ada pada indikator nomor 11 "saya mengenali profil risiko pribadi" masih kurang dipahami masyarakat, padahal jika masyarakat akan memutuskan untuk memilih portofolio investasi harus memahami dahulu profil risikonya. Selain kedua indikator tadi ada juga yang nilainya kecil yaitu nomor 12 mengenai pemahaman tentang asuransi "saya mengetahui asuransi untuk perlindungan akibat risiko yang tidak terduga" ternyata masih belum terlalu banyak yang memahami mengenai ketepatan penggunaan asuransi tersebut. Daintara 16 indikator yang memiliki nilai terbesar adalah indikator nomor 14 yaitu prinsip kehati hatian dalam mengambil kredit/hutang, masyarakat sudah paham bahwa jika berhutang atau kredit tentunya akan ada bunga yang dibebankan selain pokok pinjaman yang hal tersebut harus juga menjadi pertimbangan diawal Ketika akan mengambil hutang.

\section{KESIMPULAN}

Hasil penelitian ini memberikan kesimpulan bahwa persepsi kemafaatan berpengaruh positif terhadap Literasi keuangan, sedangkan persepsi kemudahan penggunaan tidak berpengaruh terhadap literasi keuangan. Jika dilihat dari data yang diisi oleh responden untuk variabel persepsi kemanfaatan, masyarakat sudah menyadari dan mengakui bahwa fintech membantu dalam bertransaksi, memudahkan dan praktis, sehingga dapat menghemat waktu untuk masyarakat yang ingin bertransaksi dengan produk keuangan. Jika dilihat dari hasil data responden untuk indikator yang ada dalam variabel persepsi kemudahan penggunaan, masyarakat tidak mau bergantung dengan financial tehnology, hal ini dapat dijadikan sebagai triger untuk fintech agar lebih mengedukasi masyarakat, mungkin masyarakat khawatir akan adanya kejahatan digital, dan hal ini bisa di minimalisir dengan memberikan edukasi yang baik kepada masyarakat. Dalam hasil olah data persepsi kemudahan penggunaan tidak berpengaruh terhadap literasi keuangan, hal ini dimungkinkan bisa disebabkan karena masyarakat hanya mengetahui aksesnya saja, tetapi tidak memahami secara jelas apa produk yang ditawarkan oleh fintech tersebut.

Memperhatikan bahasan hasil data responden untuk indikator dari literasi keuangan yaitu masyarakat belum terlalu paham mengenai penghitungan bunga bank dan juga belum terlalu bisa untuk mengenali profil risiko pribadi, maka financial technology sebagai media untuk masyarakat bisa masuk ke dalam inklusi keuangan dapat lebih mengedukasi 
masyarakat sehingga tingkat literasinya juga bisa bertambah sejalan dengan penambahan inklusi ke keuangan baik melalui digital dengan fintech ataupun model tradisional.

Dalam penelitian ini masih banyak perlu pengembangan variabel dan metode dalam pengukuran mengenai literasi keuangan, berdasarkan dari keterbatasan yag peneliti temukan pada saat proses penelitian, maka saran untuk peneliti selanjutnya peneliti rangkum dalam poin-poin dibawah ini: pertama, variabel penelitian untuk mewakili financial technology lebih dikembangkan lagi jika akan menggunakan dengan model TAM. Bisaditambahkan sikap dan variabel eksternal lainnya. Kedua, financial technology adalah salah satu bentuk digital untuk masyarakat bisa masuk ke dalam pemahaman mengenai keuangan, dalam hal ini tingkat inklusi keuangan. Jadi, untuk peneliti selanjutnya dapat ditambahkan variabel inklusi keuangan. Terakhir, peneliti memiliki keterbatasan menyebarkan kuesioner karena sempat mengalami pandemik Covid-19, untuk peneliti selanjutnya bisa menyebarkan kuesioner yang lebih lama waktunya sehingga jumlah responden bisa mewakili paling tidak separuh dari jumlah populasi yang ada.

\section{REFERENSI}

Akbar, D.S. (2015). Konsep Crowdfunding untuk Pendanaan Infrastrukturdi Iindonesia. Retrived from Kemenkeu: https:// kemenkeu.go.id/publikasi/artikel-danopini/ konsep-crowdfunding-untuk-pendanaan-infrastruktur-di-indonesia/ .

Aliyah, L dan Nurdin. (2019). Pengaruh Layanan Keuangan Berbasis Teknologi (Fintech) terhadap Literasi Keuangan Masyarakat Dago Atas, Bandung. Prosiding manajemen Volume 5, No.1.

Atkinson A, Messy F. (2012). Measuring financial literacy: results of the OECD / International Network on Financial Education (INFE) pilot study. Organization for Economic Cooperation and Development.

Bank Indonesia. (2014). Booklet keuangan inklusif. Jakarta: Departemen pengembangan akses keuangan dan UMKM.

Bank Indonesia. (2016). Peraturan Bank Indonesia No.18/17/PBI/ 2016 tentang uang elektronik. www.bi.go.id diakses 12 November 2019.

Chandra, E (2020). Fintech. Retrived from Financialku : https:/ / www.finansialku.com/ definisi-fintech-adalah/ .

Georgios A. P \& John O. S. Wilson (2020). Financial literacy and responsible finance in the FinTech era: capabilities and challenges. THE EUROPEAN JOURNAL OF FINANCE 2020, VOL. 26, NOS. 4-5, 297-301 https:/ / doi.org/10.1080/1351847X.2020.1717569

Hutabarat, F. (2018). Pengaruh Literasi Keuangan dan Financial Technology terhadap Inklusi Keuangan pada Masyarakat Jabodetabek. Skripsi.

Ilham, M. (2019). Implementasi Financial Inclusion Strategi di Era Ekonomi Digital terhadap Literasi Keuangan di Indonesia. Skripsi.

Nurdin, l. A. (2019). Pengaruh Layanan Keuangan Berbasis Teknologi (Fintech) terhadap Literasi Keuangan Masyarakat Dago Atas, Bandung. Prosiding Manajemen, Volume 5, No.1.

P. Walter (2019). Ap aitu Peer to Peer lending (P2P Lending)? Cari Tahu Selengkapnya. Retrived from Koinwork: https:// koinworks.com/blog/ ketahui-tentang-peer-peerlending/

Rusdianasari, F. (2018). Peran Inklusi Keuangan melalui Integrasi Fintech dalam Stabilitas Sistem Keuangan Indonesia. Jurnal Ekonomi Kuantitatif Terapan. Vol.11 No.2, Agustus 2018.

Sugiarti, E dkk. (2019). Peran Fintech dalam Meningkatkan Literasi Keuangan pada Usaha Mikro Kecil Menengah di Malang. E-JRA Vol.08 No.04 Agustus 2019.

Sugiyono, P. D. (2012). Metode Penelitian Kuantitatif Kualitatif dan R\&D. Bandung: Alfabeta.

Surendran, P. (2012). Technology Acceptance Model: A Survey of Literature. International Journal of Business and Social Research (IJBSR), Volume -2, No.-4, 175-178. 
Windayani,F.S dan Astrie. (2019). Analisis Pengaruh Faktor Demografi terhadap Literasi Keuangan dan Keputusan Investasi di Pasar Modal. E-Proceeding of Managemenrt: Vol.6,No.1 April 2019.

Organization for Economics Co-operation Development. (2016). Measuring Financial Literacy: Questionnaire and Guidance Notes for Conducting an Internationally Comparable Survey of Financial Literacy. INFE.

Otoritas Jasa Keuangan. (2016). Survei Nasional Literasi dan Keuangan Inklusi Keuangan 2016. Jakarta (ID) : OJK.

\section{Declarations}

\section{Funding}

The authors received no financial support for the research and publication of this article.

\section{Conflicts of interest/ Competing interests:}

The authors have no conflicts of interest to declare that are relevant to the content of this article.

\section{Data, Materials and/ or Code Availability:}

Data sharing is not applicable to this article as no new data were created or analyzed in this study.

\section{About the Authors}

Siti Ruhana Dara. Dosen jurusan manajemen Institut Teknologi dan Bisnis Kalbis, awal mengajar menjadi sejak tahun 2015 dengan mata kuliah yang diampu antara lain; pengenalan manajemen dan bisnis, pengenalan industri kreatif, perilaku konsumen. Tahun 2017 menjadi dosen tetap Kalbis institute dengan mengampu mata kuliah pengenalan kewirausahaan, personal finance dan manajemen keuangan. Riwayat pendidikan dalam bidang manajemen keuangan membuat penulis sekarang lebih mengkonsentrasikan pengajaran dan penelitian dalam bidang keuangan. Tertarik membuat penelitian mengenai keuangan perusahaan. Email: siti.dara@kalbis.ac.id

Mariah. Dosen jurusan manajemen Institut Teknologi dan Bisnis Kalbis, pengalaman mengajar sejak tahun 2014. Mengampu mata kuliah manajemen keuangan, pengenalan kewirausahaan, metodologi penelitian, statistik untuk bisnis, service excellence, bank dan lembaga keuangan lainnya, pengenalan pemasaran, pengenalan industry kreatif, teknik penjualan. Riwayat pendidikan dalam bidang manajemen dan riwayat pekerjaan di Bank membuat penulis tertarik melakukan penelitian mengenai perbankan dan kaitan dengan manajemen pemasaran.

\section{How to cite this Article}

Dara, S., \& Mariah, M. (2020). Peran Fintech Dalam Upaya Untuk Meningkatkan Literasi Keuangan Pada Masyarakat di Jakarta. AKURASI: Jurnal Riset Akuntansi Dan Keuangan, 2(3), 127 - 138. Retrieved from https:// ejournal.imperiuminstitute.org/ index.php/ AKURASI/ article/ view/ 240 